\title{
Klymollins T-X, Bioactive Eunicellin-Based Diterpenoids from the Soft Coral Klyxum molle
}

\section{Fang-Yu Chang ${ }^{1}$, Fang-Jung Hsu ${ }^{1}$, Chi-Jen Tai ${ }^{1}$, Wen-Chi Wei ${ }^{2}$, Ning-Sun Yang ${ }^{2,3,4, *}$ and Jyh-Horng Sheu ${ }^{1,5,6,7,8, *}$}

1 Department of Marine Biotechnology and Resources, National Sun Yat-sen University,

Kaohsiung 804, Taiwan; E-Mails: tako0225j@gmail.com (F.-Y.C.);

fangjungh@gmail.com (F.-J.H.); jean801023@hotmail.com (C.-J.T.)

2 Agricultural Biotechnology Research Center, Academia Sinica, 128 Academia Road, Section 2,

Nankang, Taipei 115, Taiwan; E-Mail: jackwei@gate.sinica.edu.tw

3 Institute of Biotechnology, National Taiwan University, Taipei 106, Taiwan

4 Department of Life Science, National Central University, Taoyuan 320, Taiwan

5 Division of Marine Biotechnology, Asia-Pacific Ocean Research Center, National Sun Yat-sen

University, Kaohsiung 804, Taiwan

6 Doctoral Degree Program in Marine Biotechnology, National Sun Yat-sen University and Academia Sinica, Kaohsiung 804, Taiwan

7 Department of Medical Research, China Medical University Hospital, China Medical University, Taichung 404, Taiwan

8 Graduate Institute of Natural Products, Kaohsiung Medical University, Kaohsiung 807, Taiwan

* Authors to whom correspondence should be addressed;

E-Mails: nsyang@gate.sinica.edu.tw (N.-S.Y.); sheu@mail.nsysu.edu.tw (J.-H.S.);

Tel.: +886-2-2787-2067 (N.-S.Y.); +886-7-525-2000 ext 5030 (J.-H.S.);

Fax: +886-2-2787-2066 (N.-S.Y.); +886-7-525-5020 (J.-H.S.).

Received: 4 January 2014; in revised form: 18 April 2014 / Accepted: 29 April 2014 /

Published: 22 May 2014

\begin{abstract}
Five new eunicellin-based diterpenoids, klymollins T-X (1-5), along with two known compounds (6 and 7) have been isolated from the soft coral Klyxum molle. The structures of these new metabolites were elucidated by extensive spectroscopic analysis and by comparison with related known compounds. Compound $\mathbf{5}$ was found to exert significant in vitro anti-inflammatory activity against LPS-stimulated RAW264.7 macrophage cells. Furthermore, compounds 4 and 7 were shown to exhibit cytotoxicity against a limited panel of human cancer cell lines.
\end{abstract}


Keywords: soft coral; Klyxum molle; eunicellin-based diterpenoids; klymollins; cytotoxic activity; anti-inflammatory activity

\section{Introduction}

Soft corals are known to be a rich source of terpenoidal metabolites [1]. Many studies about the discovery of versatile molecular structures and bioactivities of eunicellin-type compounds from soft corals have been reported recently [2-18]. Our previous studies on the secondary metabolites of a Formosan soft coral Klyxum molle have resulted in the isolation of a series of new eunicellin-based diterpenoids, klymollins A-S [19,20]. In our continuing investigation effort to discover new metabolites from the soft coral $K$. molle, we have identified five new eunicellin-type metabolites, klymollins T-X (1-5) (Chart 1 and Supplementary Figures S1-S15), along with two known eunicellin-based diterpenoids, sclerophytin A (6) and sclerophytin B (7) [21] (Chart 1). The molecular structures of these compounds, including their relative configurations, were established by detailed spectroscopic analysis and by comparison with related physical and spectral data of known compounds. The ability of compounds 1-7 to inhibit IL-6 (interlukin-6) and TNF- $\alpha$ (tumor necrosis factor $\alpha$ ) expression in LPS (lipopolysaccharide)-stimulated murine RAW264.7 macrophage cells and the cytotoxicity of 3-7 against five human cancer cell lines, human T cell lymphoblast-like cell line (CCRF-CEM), human erythromyeloblastoid leukemia (K562), human acute lymphoblastic leukemia cell line (Molt 4), human ductal breast epithelial tumor cell line (T47D) and human colorectal adenocarcinoma cell line (DLD-1) were evaluated.

Chart 1. Structures of metabolites 1-7.

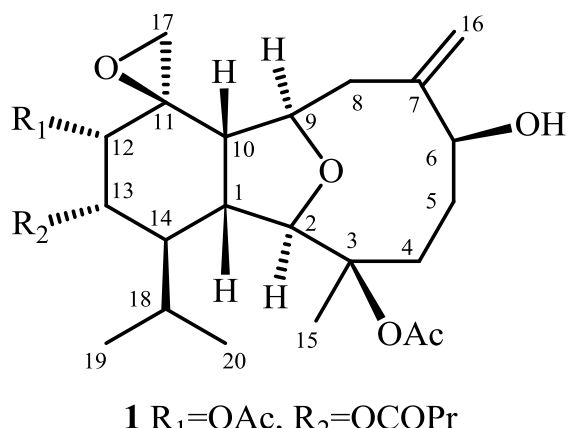

$2 \mathrm{R}_{1}=\mathrm{OCOPr}, \mathrm{R}_{2}=\mathrm{OAc}$

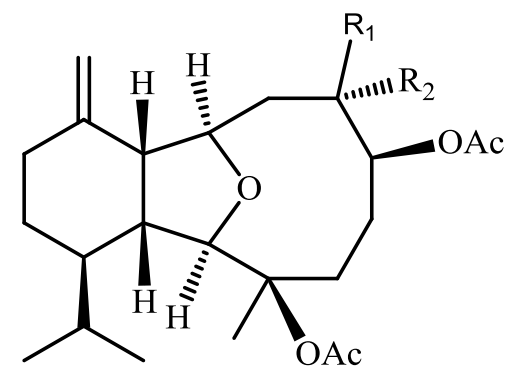

$4 \mathrm{R}_{1}=\mathrm{CH}_{3}, \mathrm{R}_{2}=\mathrm{OH}$

$5 \mathrm{R}_{1}=\mathrm{OH}, \mathrm{R}_{2}=\mathrm{CH}_{3}$

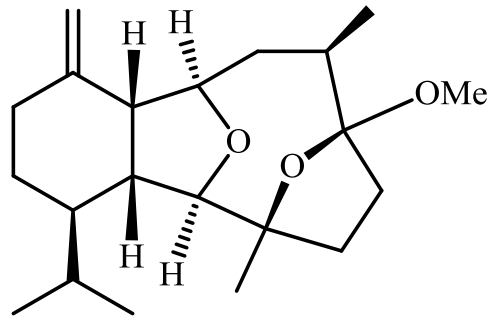

3

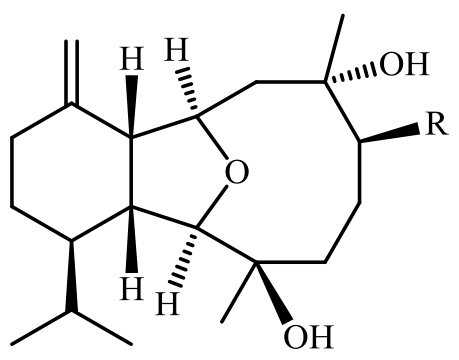

$6 \mathrm{R}=\mathrm{OH}$

$7 \mathrm{R}=\mathrm{OAc}$ 


\section{Results and Discussion}

Klymollin T (1) was obtained as a colorless oil. The HRESIMS $\left(m / z 545.2722[\mathrm{M}+\mathrm{Na}]^{+}\right)$of $\mathbf{1}$ provided its molecular formula as $\mathrm{C}_{28} \mathrm{H}_{42} \mathrm{O}_{9}$, implying the presence of eight degrees of unsaturation. The IR spectrum of 1 revealed the presence of hydroxy and carbonyl groups from absorptions at 3481 and $1746 \mathrm{~cm}^{-1}$, respectively. The ${ }^{13} \mathrm{C}$ NMR spectroscopic data of 1 exhibited 28 carbon signals (Table 1), which were assigned by the aid of DEPT spectrum to six methyls (including two acetate methyl at $\delta_{\mathrm{C}} 21.2$ and 20.8), seven methylenes (including one oxymethylene at $\delta_{\mathrm{C}} 53.0$ ), nine methines (including five oxymethines at $\delta_{\mathrm{C}} 91.6,80.6,74.2,73.0$ and 72.9), and six quaternary carbons (including three $\mathrm{sp}^{2}$ oxygenated quaternary carbons at $\delta_{\mathrm{C}} 172.0,170.1$ and 170.1, two $\mathrm{sp}^{3}$ oxygenated quaternary carbons at $\delta_{\mathrm{C}} 84.9$ and 55.7, and one sp ${ }^{2}$ quaternary carbon at $\left.\delta_{\mathrm{C}} 150.5\right)$. The NMR data of 1 in $\mathrm{C}_{6} \mathrm{D}_{6}$ (Table 1 ) showed the presence of one $n$-butyrate $\left(\delta_{\mathrm{C}} 172.0, \mathrm{C} ; 37.8, \mathrm{CH}_{2} ; 19.2, \mathrm{CH}_{2}\right.$; and $14.1, \mathrm{CH}_{3}$; and $\delta_{\mathrm{H}} 1.98,2 \mathrm{H}, \mathrm{m} ; 1.53,2 \mathrm{H}, \mathrm{m}$; and $0.83,3 \mathrm{H}, \mathrm{t}, J=7.5 \mathrm{~Hz}$ ), one 1,1-disubstituted double bond $\left(\delta_{\mathrm{C}} 116.9, \mathrm{CH}_{2}\right.$ and $150.5, \mathrm{C}$; and $\delta_{\mathrm{H}} 5.24,1 \mathrm{H}, \mathrm{d}, J=2.0 \mathrm{~Hz}$ and $4.86,1 \mathrm{H}$, brs), one terminal epoxide $\left(\delta_{\mathrm{C}} 53.0, \mathrm{CH}_{2}\right.$ and $55.7, \mathrm{C} ; \delta_{\mathrm{H}} 2.31, \mathrm{~d}$ and 1.99 , d, each $\left.1 \mathrm{H}, J=5.0 \mathrm{~Hz}\right)$ and two acetate groups $\left(\delta_{\mathrm{C}} 170.1, \mathrm{C} ; 170.1, \mathrm{C} ; 20.8, \mathrm{CH}_{3}\right.$ and $21.2, \mathrm{CH}_{3}$; and $\delta_{\mathrm{H}} 1.62$, s, and 1.82 , s, each $3 \mathrm{H}$ ), respectively. Analysis of HMQC correlations showed that proton signals appearing at $\delta_{\mathrm{H}} 2.33(1 \mathrm{H}, \mathrm{m}), 2.17(1 \mathrm{H}, \mathrm{t}$, $J=8.5 \mathrm{~Hz}), 3.97(1 \mathrm{H}, \mathrm{br} \mathrm{s})$, and $5.00(1 \mathrm{H}, \mathrm{d}, J=5.5 \mathrm{~Hz})$ were correlated to two ring juncture methine carbons at $\delta_{\mathrm{C}} 42.4$ and 43.5 and two oxymethine carbons at $\delta_{\mathrm{C}} 91.6$ and 80.6, respectively. Therefore, the remaining three degrees of unsaturation identified $\mathbf{1}$ as a tricyclic diterpenoid. In addition, the COSY correlations of $\mathbf{1}$ assigned three isolated consecutive proton spin systems (Figure 1). The molecular framework of 1 was further established by HMBC correlations (Figure 1). Furthermore, $\mathrm{H}-12(\delta 5.24)$ and an acetate methyl $(\delta$ 1.62) exhibited HMBC correlations to the acetate carbonyl carbon $(\delta 170.1)$, and H-13 exhibited HMBC correlation to the $n$-butyrate carbonyl carbon $(\delta 172.0)$, revealing the location of an acetate at $\mathrm{C}-12$ and an $n$-butyrate at $\mathrm{C}-13$. The location of an acetate group at $\mathrm{C}-3$ was then deduced by the chemical shifts of $\mathrm{C}-3(\delta 84.9)$ and $\mathrm{H}_{3}-15(\delta 1.75)$. From the above results, the structure of compound $\mathbf{1}$ was shown to be related to that of the known compound, klymollin C [19]. Comparison of the NMR data of them revealed that the replacement of the acetoxy group at C-13 in klymollin $\mathrm{C}$ by an $n$-butyryloxy group in $\mathbf{1}$.

Figure 1. Selected COSY $(-)$ and $\operatorname{HMBC}(\rightarrow)$ correlations of $\mathbf{1}, \mathbf{3}$ and $\mathbf{4}$.
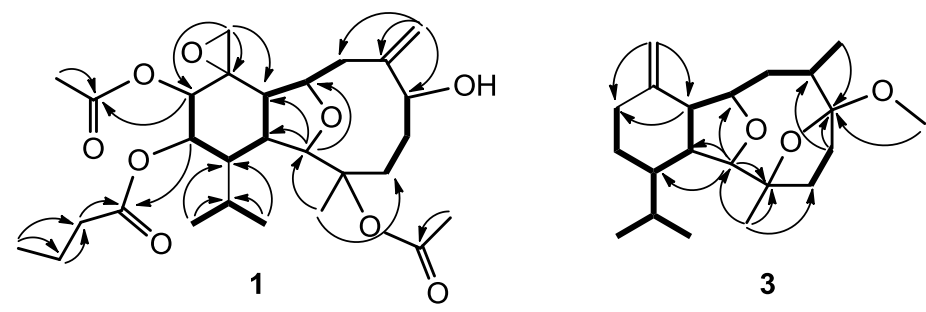

3

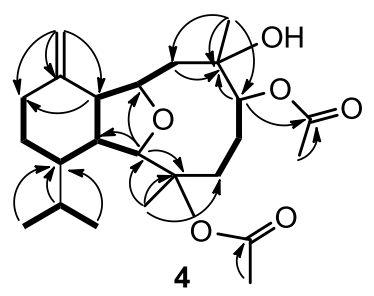


The relative configuration of $\mathbf{1}$ was determined by comparison of the chemical shifts with klymollin $\mathrm{C}$ and was further confirmed by NOE correlations (Figure 2). The NOE correlations between $\mathrm{H}-12$ and $\mathrm{H}-13$, and between $\mathrm{H}-13$ with $\mathrm{H}-1, \mathrm{H}-10$ and $\mathrm{H}-12$ suggested that $\mathrm{H}-12$ and $\mathrm{H}-13$ were $\beta$-oriented and the relative configuration of 1 was proposed as $1 R^{*}, 2 R^{*}, 3 R^{*}, 6 S^{*}, 9 R^{*}, 10 S^{*}, 11 S^{*}$, $12 S^{*}, 13 S^{*}$ and $14 R^{*}$.

Figure 2. Key NOESY Correlations for 1.

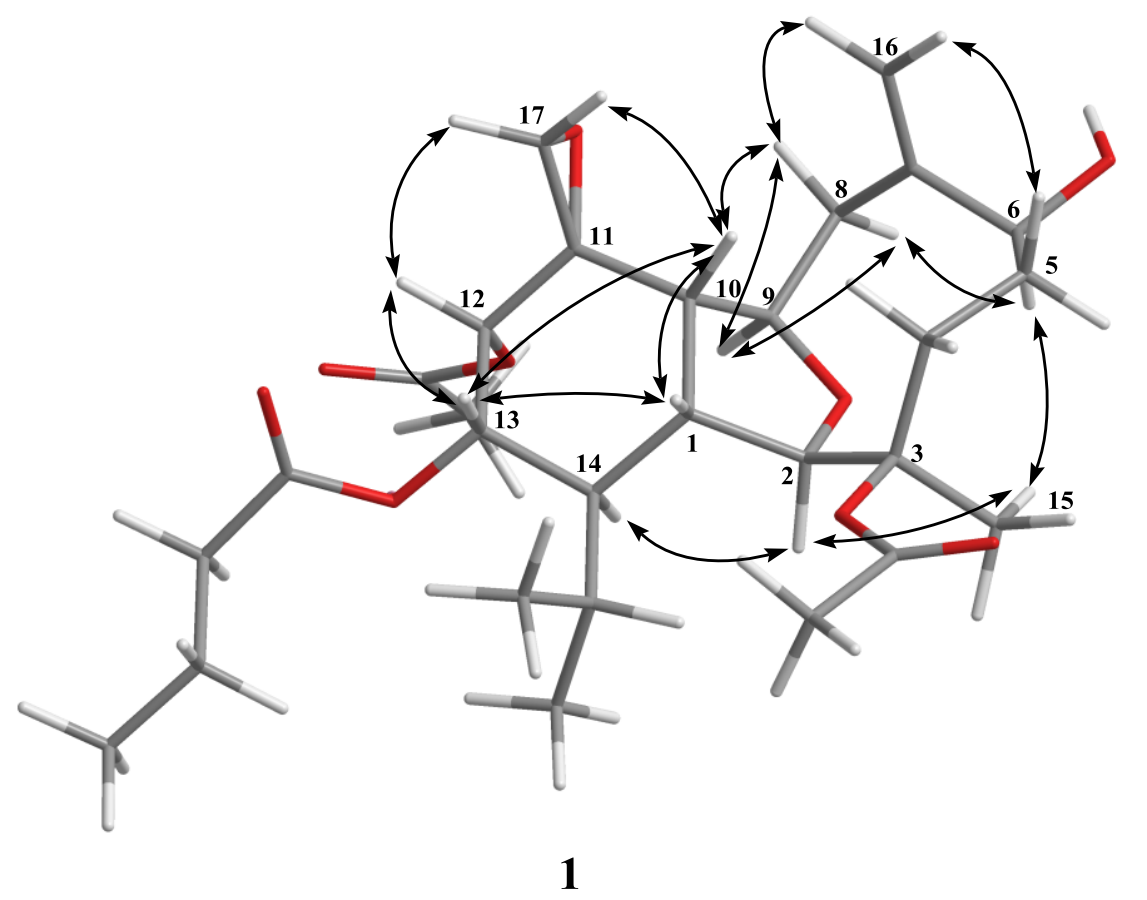

The HRESIMS of klymollin U (2) exhibited a $[\mathrm{M}+\mathrm{Na}]^{+}$peak at $\mathrm{m} / z 545.2723$ established the same molecular formula as that of $\mathbf{1}$. The ${ }^{1} \mathrm{H}$ and ${ }^{13} \mathrm{C}$ NMR data of $\mathbf{2}$ (Table 1) were similar to those of $\mathbf{1}$, revealed the presence of two acetoxy groups $\left(\delta_{\mathrm{C}} 170.0, \mathrm{C} ; 169.4, \mathrm{C} ; 22.5, \mathrm{CH}_{3}\right.$ and $21.1, \mathrm{CH}_{3}$; and $\delta_{\mathrm{H}} 2.00, \mathrm{~s}, 3 \mathrm{H}$ and $\left.1.92, \mathrm{~s}, 3 \mathrm{H}\right)$, one $n$-butyryloxy group $\left(\delta_{\mathrm{C}} 172.6, \mathrm{C} ; 36.5, \mathrm{CH}_{2} ; 18.8, \mathrm{CH}_{2} ; 13.5, \mathrm{CH}_{3}\right.$; and $\left.\delta_{\mathrm{H}} 2.38, \mathrm{~m}, 2 \mathrm{H} ; 1.70, \mathrm{~m}, 2 \mathrm{H} ; 1.00, \mathrm{t}, 3 \mathrm{H}, J=7.6 \mathrm{~Hz}\right)$, one 1,1-disubstituted double bond $\left(\delta_{\mathrm{C}} 116.8\right.$, $\mathrm{CH}_{2}$ and $150.0, \mathrm{C}$; and $\delta_{\mathrm{H}} 5.36$, brs and 4.98 , brs, each $\left.1 \mathrm{H}\right)$, one terminal epoxide $\left(\delta_{\mathrm{C}} 53.6, \mathrm{CH}_{2}\right.$ and $55.2, \mathrm{C} ; \delta_{\mathrm{H}} 2.87, \mathrm{~d}$ and $2.64, \mathrm{~d}$, each $1 \mathrm{H}, J=4.8 \mathrm{~Hz}$ ). The positions of one $n$-butyrate group and one acetate group at C-12 and C-13, respectively, was confirmed by the HMBC correlations of $\mathrm{H}-12$ and the oxymethylene protons $\left(\delta_{\mathrm{H}} 2.38\right)$ to the $n$-butyryloxy carbonyl carbon $(\delta 172.6)$, and $\mathrm{H}-13$ and an acetate methyl $\left(\delta_{\mathrm{H}} 2.00\right)$ to the acetate carbonyl carbon $(\delta 170.0)$. Thus, the remaining one acetate group had to be positioned at $\mathrm{C}-3$, an oxygen-bearing quaternary carbon resonating at $\delta 84.6 \mathrm{ppm}$. A more detailed analysis of the ${ }^{1} \mathrm{H}$ and ${ }^{13} \mathrm{C}$ NMR spectroscopic data and correlations in the ${ }^{1} \mathrm{H}-{ }^{1} \mathrm{H}$ COSY and HMBC spectra led to the establishment of the gross structure of 2 (Figure 1). The stereochemistry of $\mathbf{2}$ was finally confirmed by comparison of its NMR data and NOE correlations with 1. 
Table 1. ${ }^{13} \mathrm{C}$ and ${ }^{1} \mathrm{H}$ NMR data for compounds $\mathbf{1}-\mathbf{3}$.

\begin{tabular}{|c|c|c|c|c|c|c|}
\hline & \multicolumn{2}{|c|}{$1^{a}$} & \multicolumn{2}{|l|}{$2^{b}$} & \multicolumn{2}{|l|}{$3^{b}$} \\
\hline & $\boldsymbol{\delta}_{\mathbf{H}}$ & $\boldsymbol{\delta}_{\mathbf{C}}$ & $\delta_{\mathrm{H}}$ & $\delta_{\mathrm{C}}$ & $\boldsymbol{\delta}_{\mathbf{H}}$ & $\delta_{\mathrm{C}}$ \\
\hline 1 & $2.33 \mathrm{~m}$ & $42.4(\mathrm{CH})^{\mathrm{c}}$ & $2.38 \mathrm{t}(7.2)^{\mathrm{d}}$ & $41.8(\mathrm{CH})$ & $2.20 \mathrm{~m}$ & $46.0(\mathrm{CH})$ \\
\hline 2 & 3.97 brs $^{\mathrm{e}}$ & $91.6(\mathrm{CH})$ & 3.79 brs & $90.8(\mathrm{CH})$ & 3.58 brs & $90.9(\mathrm{CH})$ \\
\hline 3 & & $84.9(\mathrm{C})$ & & $84.6(\mathrm{C})$ & & $86.7(\mathrm{C})$ \\
\hline \multirow[t]{2}{*}{4} & $1.49 \mathrm{~m}$ & $28.5\left(\mathrm{CH}_{2}\right)$ & $1.53 \mathrm{~m}$ & $27.8\left(\mathrm{CH}_{2}\right)$ & $2.10 \mathrm{~m}$ & $37.6\left(\mathrm{CH}_{2}\right)$ \\
\hline & $2.35 \mathrm{~m}$ & & $2.26 \mathrm{~m}$ & & $1.80 \mathrm{t}(10.8)$ & \\
\hline \multirow[t]{2}{*}{5} & $1.62 \mathrm{~m}$ & $34.4\left(\mathrm{CH}_{2}\right)$ & $1.69 \mathrm{~m}$ & $34.3\left(\mathrm{CH}_{2}\right)$ & $2.76 \mathrm{~m}$ & $32.8\left(\mathrm{CH}_{2}\right)$ \\
\hline & $2.30 \mathrm{~m}$ & & $2.20 \mathrm{~m}$ & & $1.92 \mathrm{t}(12.0)$ & \\
\hline 6 & $4.24 \mathrm{dd}(9.5,4.0)^{\mathrm{d}}$ & $73.0(\mathrm{CH})$ & $4.29 \mathrm{~d}(8.0)$ & $72.5(\mathrm{CH})$ & & $113.4(\mathrm{C})$ \\
\hline 7 & & $150.5(\mathrm{C})$ & & $150.0(\mathrm{C})$ & $2.16 \mathrm{~m}$ & $38.8(\mathrm{CH})$ \\
\hline \multirow[t]{2}{*}{8} & $2.57 \mathrm{~d}(13.5)$ & $41.4\left(\mathrm{CH}_{2}\right)$ & $2.48 \mathrm{~d}(13.6)$ & $40.7\left(\mathrm{CH}_{2}\right)$ & $2.41 \mathrm{ddd}(16.0,6.8,3.2)$ & $36.0\left(\mathrm{CH}_{2}\right)$ \\
\hline & $2.71 \mathrm{dd}(13.5,4.0)$ & & $2.78 \mathrm{dd}(13.6,4.0)$ & & $1.68 \mathrm{~m}$ & \\
\hline 9 & $5.00 \mathrm{~d}(5.5)$ & $80.6(\mathrm{CH})$ & $4.90 \mathrm{~m}$ & $80.1(\mathrm{CH})$ & $4.05 \mathrm{dt}(8.8,3.2)$ & $82.1(\mathrm{CH})$ \\
\hline 10 & $2.17 \mathrm{t}(8.5)$ & $43.5(\mathrm{CH})$ & $2.26 \mathrm{t}(10.4)$ & $42.9(\mathrm{CH})$ & $3.92 \mathrm{t}(8.0)$ & $46.6(\mathrm{CH})$ \\
\hline 11 & & $55.7(\mathrm{C})$ & & $55.2(\mathrm{C})$ & & $148.1(\mathrm{C})$ \\
\hline \multirow[t]{2}{*}{12} & $5.24 \mathrm{~d}(2.0)$ & $74.2(\mathrm{CH})$ & 4.92 brs & $73.6(\mathrm{CH})$ & $2.02 \mathrm{~m}$ & $31.2\left(\mathrm{CH}_{2}\right)$ \\
\hline & & & & & $2.20 \mathrm{~m}$ & \\
\hline \multirow[t]{2}{*}{13} & $5.11 \mathrm{dd}(11.0,2.0)$ & $72.9(\mathrm{CH})$ & $4.91 \mathrm{~d}(10.4)$ & $72.2(\mathrm{CH})$ & $0.99 \mathrm{~m}$ & $24.9\left(\mathrm{CH}_{2}\right)$ \\
\hline & & & & & $1.70 \mathrm{~m}$ & \\
\hline 14 & $2.11 \mathrm{~m}$ & $41.8(\mathrm{CH})$ & $2.01 \mathrm{~m}$ & $40.7(\mathrm{CH})$ & $1.26 \mathrm{~m}$ & $43.2(\mathrm{CH})$ \\
\hline 15 & $1.75 \mathrm{~s}$ & $22.9\left(\mathrm{CH}_{3}\right)$ & $1.65 \mathrm{~s}$ & $22.1\left(\mathrm{CH}_{3}\right)$ & $1.31 \mathrm{~s}$ & $23.2\left(\mathrm{CH}_{3}\right)$ \\
\hline \multirow[t]{2}{*}{16} & $5.24 \mathrm{~d}(2.0)$ & $116.9\left(\mathrm{CH}_{2}\right)$ & $4.98 \mathrm{brs}$ & $116.8\left(\mathrm{CH}_{2}\right)$ & $1.36 \mathrm{~d}(7.6)$ & $19.1\left(\mathrm{CH}_{3}\right)$ \\
\hline & 4.86 brs & & $5.36 \mathrm{brs}$ & & & \\
\hline \multirow[t]{2}{*}{17} & $1.99 \mathrm{~d}(5.0)$ & $53.0\left(\mathrm{CH}_{2}\right)$ & $2.64 \mathrm{~d}(4.8)$ & $53.6\left(\mathrm{CH}_{2}\right)$ & $4.77 \mathrm{brs}$ & $109.8\left(\mathrm{CH}_{2}\right)$ \\
\hline & $2.31 \mathrm{~d}(5.0)$ & & $2.87 \mathrm{~d}(4.8)$ & & $4.70 \mathrm{~d}(1.2)$ & \\
\hline 18 & $2.06 \mathrm{~m}$ & $28.3(\mathrm{CH})$ & $2.03 \mathrm{~m}$ & $27.3(\mathrm{CH})$ & $1.70 \mathrm{~m}$ & $29.1(\mathrm{CH})$ \\
\hline 19 & $0.89 \mathrm{~d}(7.0)$ & $16.3\left(\mathrm{CH}_{3}\right)$ & $0.84 \mathrm{~d}(7.2)$ & $15.3\left(\mathrm{CH}_{3}\right)$ & $0.95 \mathrm{~d}(6.8)$ & $21.9\left(\mathrm{CH}_{3}\right)$ \\
\hline 20 & $1.12 \mathrm{~d}(7.0)$ & $24.5\left(\mathrm{CH}_{3}\right)$ & $1.09 \mathrm{~d}(7.2)$ & $24.0\left(\mathrm{CH}_{3}\right)$ & $0.76 \mathrm{~d}(6.8)$ & $15.4\left(\mathrm{CH}_{3}\right)$ \\
\hline \multirow[t]{2}{*}{ 3-OAc } & & $170.1(\mathrm{C})$ & & $169.4(\mathrm{C})$ & & \\
\hline & $1.82 \mathrm{~s}$ & $21.2\left(\mathrm{CH}_{3}\right)$ & $1.92 \mathrm{~s}$ & $22.5\left(\mathrm{CH}_{3}\right)$ & & \\
\hline 6-OMe & & & & & $3.26 \mathrm{brs}$ & $48.5\left(\mathrm{CH}_{3}\right)$ \\
\hline \multirow[t]{2}{*}{$12-\mathrm{OAc}$} & & $170.1(\mathrm{C})$ & & & & \\
\hline & $1.62 \mathrm{~s}$ & $20.8\left(\mathrm{CH}_{3}\right)$ & & & & \\
\hline \multirow[t]{4}{*}{ 12-OCOPr } & & & & $172.6(\mathrm{C})$ & & \\
\hline & & & $2.38 \mathrm{~m}$ & $36.5\left(\mathrm{CH}_{2}\right)$ & & \\
\hline & & & $1.70 \mathrm{~m}$ & $18.8\left(\mathrm{CH}_{2}\right)$ & & \\
\hline & & & $1.00 \mathrm{t}(7.6)$ & $13.5\left(\mathrm{CH}_{3}\right)$ & & \\
\hline \multirow[t]{2}{*}{ 13-OAc } & & & & $170.0(\mathrm{C})$ & & \\
\hline & & & $2.00 \mathrm{~s}$ & $21.1\left(\mathrm{CH}_{3}\right)$ & & \\
\hline \multirow[t]{4}{*}{ 13-OCOPr } & & $172.0(\mathrm{C})$ & & & & \\
\hline & $1.98 \mathrm{~m}$ & $37.8\left(\mathrm{CH}_{2}\right)$ & & & & \\
\hline & $1.53 \mathrm{~m}$ & $19.2\left(\mathrm{CH}_{2}\right)$ & & & & \\
\hline & $0.83 \mathrm{t}(7.5)$ & $14.1\left(\mathrm{CH}_{3}\right)$ & & & & \\
\hline
\end{tabular}

${ }^{\mathrm{a}}{ }^{13} \mathrm{C}$ and ${ }^{1} \mathrm{H}$ spectra recorded at 125 and $500 \mathrm{MHz}$ in $\mathrm{C}_{6} \mathrm{D}_{6} ;{ }^{\mathrm{b}}{ }^{13} \mathrm{C}$ and ${ }^{1} \mathrm{H}$ spectra recorded at 100 and $400 \mathrm{MHz}$ in $\mathrm{CDCl}_{3} ;{ }^{\mathrm{c}}$ Deduced from DEPT; ${ }^{\mathrm{d}} J$ values $(\mathrm{Hz})$ in parentheses; ${ }^{\mathrm{e}}$ Broad signal. 
Molecular formula $\mathrm{C}_{21} \mathrm{H}_{34} \mathrm{O}_{3}$ with five degrees of unsaturation was assigned to klymollin $\mathrm{V}$ (3) from its HRESIMS data $\left(\mathrm{m} / \mathrm{z} 357.2405[\mathrm{M}+\mathrm{Na}]^{+}\right)$. The NMR spectroscopic data of 3 (Table 1) showed the presence of one 1,1-disubstituted double bond $\left(\delta_{\mathrm{C}} 109.8, \mathrm{CH}_{2}\right.$ and 148.1, $\mathrm{C} ; \delta_{\mathrm{H}} 4.77$, brs and $4.70, \mathrm{~d}, J=1.2 \mathrm{~Hz}$, each $1 \mathrm{H})$ and a methoxyl group $\left(\delta_{\mathrm{H}} 3.26,3 \mathrm{H}, \mathrm{brs}\right)$. Analysis of HMQC, COSY and $\mathrm{HMBC}$ correlations (Figure 1) showed that proton signals appearing at $\delta_{\mathrm{H}} 2.20(1 \mathrm{H}, \mathrm{m}), 3.92(1 \mathrm{H}$, $\mathrm{t}, J=8.0 \mathrm{~Hz}), 3.58(1 \mathrm{H}, \mathrm{brs})$, and $4.05(1 \mathrm{H}, \mathrm{dt}, J=8.8$ and $3.2 \mathrm{~Hz})$ were correlated to two ring-juncture methine carbons at $\delta_{\mathrm{C}} 46.0$ and 46.6 and two oxymethine carbons at $\delta_{\mathrm{C}} 90.9$ and 82.1 , respectively. Furthermore, one oxygenated quaternary carbon $\delta_{\mathrm{C}} 86.7$ (C-3) and one deoxygenated quaternary carbon $\delta_{\mathrm{C}} 113.4$ (C-6), implied that C-3 and C-6 were linked through an oxygen to form a tetrahydrofuran ring. The HMBC correlation of the methoxyl protons $(\delta 3.26)$ to $\mathrm{C}-6$ ( $\delta$ 113.4) suggested the substitution of a methoxyl group at C-6. Thus, the molecular framework of $\mathbf{3}$ was established. The relative stereochemistry of $\mathbf{3}$ was deduced by careful interpretation of the NOE correlations (Figure 3). The key NOE correlations of $\mathbf{3}$ showed interactions between $\mathrm{H}-1$ and H-10, and $\mathrm{H}_{3}-15 ; \mathrm{H}-10$ and $\mathrm{H}_{3}-16$ and $\mathrm{H}-17 \mathrm{a}$ ( $\delta$ 4.77); and $\mathrm{H}_{3}-15$ and 6-OMe. Thus, all of $\mathrm{H}-1, \mathrm{H}-10, \mathrm{H}_{3}-15$, $\mathrm{H}_{3}-16$ and 6-OMe should be the $\beta$ face. NOE correlations were also detected between $\mathrm{H}-14$ and $\mathrm{H}-2$, $\mathrm{H}-2$ and $\mathrm{H}-4 \alpha(\delta 2.10)$, revealing the $\alpha$-orientation of both $\mathrm{H}-2$ and $\mathrm{H}-14$, as suggested by a molecular model of $\mathbf{3}$ (Figure 3). On the basis of the above findings, the structure of compound $\mathbf{3}$, including the relative stereochemistry, was unambiguously established.

Figure 3. Key NOESY Correlations for $\mathbf{3}$ and $\mathbf{4}$.
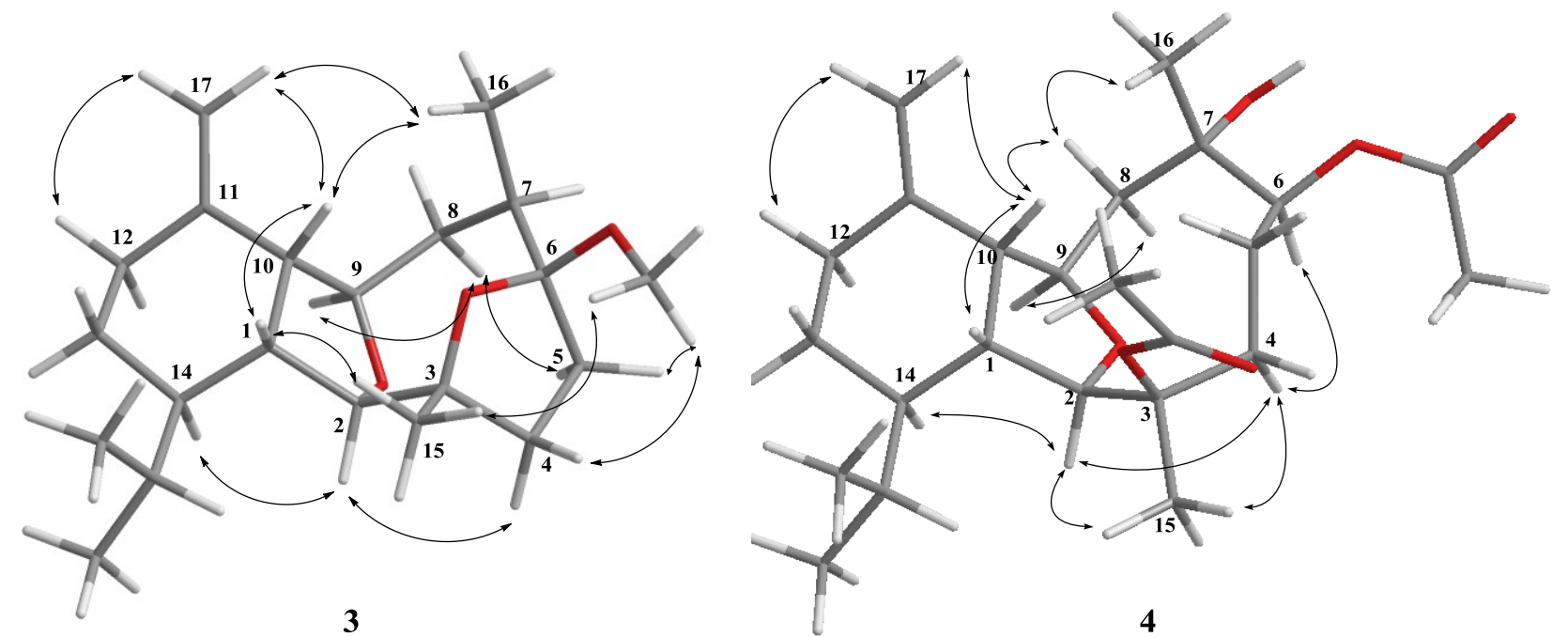

Klymollin W (4) showed the pseudomolecular ion peak $[\mathrm{M}+\mathrm{Na}]^{+}$at $m / z 445.2563$ in the HRESIMS and the molecular formula was determined as $\mathrm{C}_{24} \mathrm{H}_{38} \mathrm{O}_{6}$. NMR spectroscopic data of 4 (Table 2) showed the presence of two acetoxy groups $\left(\delta_{\mathrm{C}} 171.9,169.6,22.4\right.$ and $21.4 ; \delta_{\mathrm{H}} 2.11$, s and 2.08 , s, each $3 \mathrm{H}$ ). The NMR data of 4 was found to be similar to those of known compound 7 [15], the only difference is the replacement of the hydroxy group at C-3 in 7 by one acetoxy group in 4 . The stereochemistry of compound $\mathbf{4}$ was also determined by the NOESY spectrum (Figure 3), which exhibited NOE correlations of $\mathrm{H}-10$ with $\mathrm{H}-1$ and $\mathrm{H}-8 \beta(\delta 2.04), \mathrm{H}-8 \beta$ with $\mathrm{H}_{3}-16$, establishing the $\beta$-orientation of $\mathrm{H}_{3}-16$. On the basis of these results and observed NOE correlations (Figure 3 ), the structure of metabolite 4 was determined. 
Table 2. ${ }^{13} \mathrm{C}$ and ${ }^{1} \mathrm{H}$ NMR data for compounds 4 and $\mathbf{5}$.

\begin{tabular}{|c|c|c|c|c|}
\hline & \multicolumn{2}{|l|}{4} & \multicolumn{2}{|l|}{5} \\
\hline & $\delta_{H}$ & $\boldsymbol{\delta}_{\mathbf{C}}$ & $\delta_{H}$ & $\delta_{\mathbf{C}}$ \\
\hline 1 & $2.18 \mathrm{~m}$ & $45.7(\mathrm{CH})^{\mathrm{a}}$ & $2.19 \mathrm{~m}$ & $45.9(\mathrm{CH})$ \\
\hline 2 & 3.63 brs $^{b}$ & $92.1(\mathrm{CH})$ & 3.59 brs & $92.3(\mathrm{CH})$ \\
\hline 3 & & $86.7(\mathrm{C})$ & & $86.4(\mathrm{C})$ \\
\hline \multirow[t]{2}{*}{4} & $2.04 \mathrm{~m}$ & $35.7\left(\mathrm{CH}_{2}\right)$ & $1.94 \mathrm{~m}$ & $35.6\left(\mathrm{CH}_{2}\right)$ \\
\hline & $2.60 \mathrm{dd}(15.6,8.8)^{\mathrm{c}}$ & & $2.63 \mathrm{~m}$ & \\
\hline \multirow[t]{2}{*}{5} & $1.26 \mathrm{~m}$ & $29.2\left(\mathrm{CH}_{2}\right)$ & $1.37 \mathrm{~m}$ & $27.4\left(\mathrm{CH}_{2}\right)$ \\
\hline & $1.59 \mathrm{~m}$ & & $1.95 \mathrm{~m}$ & \\
\hline 6 & $5.63 \mathrm{~d}(6.0)$ & $84.7(\mathrm{CH})$ & $5.22 \mathrm{~d}(6.0)$ & $83.4(\mathrm{CH})$ \\
\hline 7 & & $75.6(\mathrm{C})$ & & $72.9(\mathrm{C})$ \\
\hline \multirow[t]{2}{*}{8} & $1.86 \mathrm{~m}$ & $45.9\left(\mathrm{CH}_{2}\right)$ & $1.81 \mathrm{dd}(14.0,3.6)$ & $45.2\left(\mathrm{CH}_{2}\right)$ \\
\hline & $2.04 \mathrm{~m}$ & & $2.08 \mathrm{~m}$ & \\
\hline 9 & $4.17 \mathrm{q}(7.2)$ & $78.1(\mathrm{CH})$ & 3.85 ddd $(3.6,7.6,11.2)$ & $78.6(\mathrm{CH})$ \\
\hline 10 & $2.98 \mathrm{t}(7.2)$ & $53.8(\mathrm{CH})$ & $3.06 \mathrm{t}(7.6)$ & $53.8(\mathrm{CH})$ \\
\hline 11 & & $147.6(\mathrm{C})$ & & $147.4(\mathrm{C})$ \\
\hline \multirow[t]{2}{*}{12} & $2.04 \mathrm{~m}$ & $31.5\left(\mathrm{CH}_{2}\right)$ & $2.05 \mathrm{~m}$ & $31.6\left(\mathrm{CH}_{2}\right)$ \\
\hline & $2.28 \mathrm{~m}$ & & $2.31 \mathrm{~m}$ & \\
\hline \multirow[t]{2}{*}{13} & $1.02 \mathrm{~m}$ & $24.6\left(\mathrm{CH}_{2}\right)$ & $1.02 \mathrm{~m}$ & $24.6\left(\mathrm{CH}_{2}\right)$ \\
\hline & $1.72 \mathrm{~m}$ & & $1.72 \mathrm{~m}$ & \\
\hline 14 & $1.29 \mathrm{~m}$ & $43.9(\mathrm{CH})$ & $1.23 \mathrm{~m}$ & $43.9(\mathrm{CH})$ \\
\hline 15 & $1.39 \mathrm{~s}$ & $22.9\left(\mathrm{CH}_{3}\right)$ & $1.38 \mathrm{~s}$ & $23.1\left(\mathrm{CH}_{3}\right)$ \\
\hline 16 & $1.20 \mathrm{~s}$ & $23.7\left(\mathrm{CH}_{3}\right)$ & $1.27 \mathrm{~s}$ & $25.4\left(\mathrm{CH}_{3}\right)$ \\
\hline \multirow[t]{2}{*}{17} & 4.62 brs & $109.5\left(\mathrm{CH}_{2}\right)$ & $4.64 \mathrm{brs}$ & $109.9\left(\mathrm{CH}_{2}\right)$ \\
\hline & $4.68 \mathrm{brs}$ & & $4.71 \mathrm{brs}$ & \\
\hline 18 & $1.72 \mathrm{~m}$ & $29.0(\mathrm{CH})$ & $1.74 \mathrm{~m}$ & $29.0(\mathrm{CH})$ \\
\hline 19 & $0.97 \mathrm{~d}(7.2)$ & $21.9\left(\mathrm{CH}_{3}\right)$ & $0.98 \mathrm{~d}(7.2)$ & $21.9\left(\mathrm{CH}_{3}\right)$ \\
\hline 20 & $0.79 \mathrm{~d}(7.2)$ & $15.4\left(\mathrm{CH}_{3}\right)$ & $0.79 \mathrm{~d}(7.2)$ & $15.4\left(\mathrm{CH}_{3}\right)$ \\
\hline \multirow[t]{2}{*}{ 3-OAc } & & $169.6(\mathrm{C})$ & & $169.6(\mathrm{C})$ \\
\hline & $2.11 \mathrm{~s}$ & $22.4\left(\mathrm{CH}_{3}\right)$ & $2.13 \mathrm{~s}$ & $22.5\left(\mathrm{CH}_{3}\right)$ \\
\hline \multirow[t]{2}{*}{ 6-OAc } & & $171.9(\mathrm{C})$ & & $170.1(\mathrm{C})$ \\
\hline & $2.08 \mathrm{~s}$ & $21.4\left(\mathrm{CH}_{3}\right)$ & $2.08 \mathrm{~s}$ & $21.3\left(\mathrm{CH}_{3}\right)$ \\
\hline
\end{tabular}

${ }^{13} \mathrm{C}$ and ${ }^{1} \mathrm{H}$ spectra recorded at 100 and $400 \mathrm{MHz}$ in $\mathrm{CDCl}_{3} ;{ }^{\text {a }}$ Deduced from DEPT; ${ }^{\mathrm{b}}$ Broad signal; ${ }^{\mathrm{c}} J$ values $(\mathrm{Hz})$ in parentheses.

The HRESIMS of klymollin X (5) exhibited a $[\mathrm{M}+\mathrm{Na}]^{+}$ion peak at $\mathrm{m} / z$ 445.2563, which was consistent with the molecular formula of $\mathrm{C}_{24} \mathrm{H}_{38} \mathrm{O}_{6}$. Furthermore, it was found that the NMR data of 5 (Table 2) were very similar to those of $\mathbf{4}$, suggesting that $\mathbf{5}$ might be a regioisomer of $\mathbf{4}$. From NOESY spectrum, it was found that the $\alpha$-oriented H-9 ( $\delta 3.85)$ showed NOE interaction with $\mathrm{H}-8 \alpha(\delta 1.81)$, and the later exhibited further interaction with $\mathrm{H}_{3}-16$. This inferred the $\alpha$-orientation of the methyl substituent at C-7. Further analysis of other NOE interactions revealed that $\mathbf{5}$ possessed the same relative configurations at C-1, C-2, C-3, C-9, C-10, C-12 and C-14 as those of 4. Therefore, compound 5 was found to be the C-7 epimer of 4. 
Eunicellin-type diterpenoids isolated from Formosan soft corals was reported to have anti-inflammatory activities [22]. Therefore, the in vitro anti-inflammatory effects of compounds 1-7 were tested by examining the inhibitory activity of these compounds toward the LPS-induced up-regulation of pro-inflammatory proteins, IL-6 and TNF- $\alpha$ in murine RAW264.7 macrophage cells (Figure 4). At a concentration of $25 \mu \mathrm{M}$, compound 5 significantly reduce the level of IL-6, relative to the control cells stimulated with LPS only. However, these metabolites did not reduce the expression of TNF- $\alpha$ effectively. The cytotoxicity of the diterpenoids 3-7 against five human carcinoma cell lines, CCRF-CEM, K562, Molt 4, T47D and DLD-1 were also evaluated by the MTT assay. Cytotoxicity of 1 and $\mathbf{2}$ was not measured due to the paucity of these two compounds. Among the tested compounds, 7 showed stronger activity against the proliferation of four cancer cell lines $\left(\mathrm{ED}_{50}\right.$ values of CCRF-CEM, K562, Molt 4 and T47D were 4.2, 15.0, 16.5 and $12.4 \mu \mathrm{g} / \mathrm{mL}$ ), and 4 exhibited cytotoxicity toward CCRF-CEM, Molt 4 and T47D cancer cell lines with $\mathrm{ED}_{50}$ values of 9.6, 8.5 and $19.9 \mu \mathrm{g} / \mathrm{mL}$, respectively. These results together with our previous findings [19,20], demonstrated that the soft coral $K$. molle is a good source of bioactive substances which deserve for further biomedical investigations.

Figure 4. Effect of compounds 1-7 on LPS-induced IL-6 and TNF- $\alpha$ expression in RAW264.7 macrophage cells by ELISA analysis. The values are mean \pm SEM. $(n=6)$. Relative intensity of the LPS alone stimulated group was taken as $100 \%$. * Significantly different from LPS alone stimulated group $(P<0.05) .{ }^{a}$ stimulated with LPS, ${ }^{\mathrm{b}}$ stimulated with LPS in the presence of 1-7 $(25 \mu \mathrm{M})$.
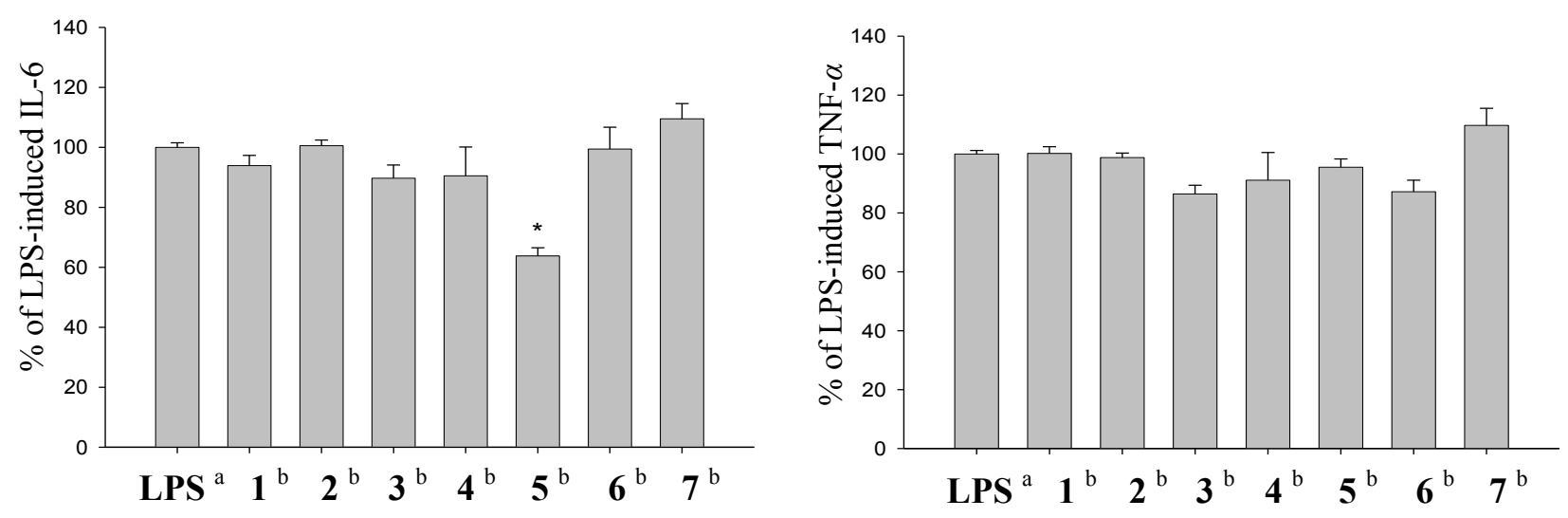

\section{Experimental Section}

\subsection{General Experimental Procedures}

Optical rotations were measured on a JASCO P-1020 polarimeter. IR spectra were recorded on a JASCO FT/IR-4100 infrared spectrophotometer. ESIMS and HRESIMS were obtained with a Bruker APEX II mass spectrometer. NMR spectra were recorded in $\mathrm{C}_{6} \mathrm{D}_{6}$ or $\mathrm{CDCl}_{3}$, either on a Varian UNITY INOVA-500 FT-NMR, a Varian 400MR FT-NMR, or a Bruker AMX-300 FT-NMR. Silica gel (230-400 mesh, Merck, Darmstadt, Germany) was used for column chromatography. Precoated silica gel plates (Kieselgel 60 F-254, $0.2 \mathrm{~mm}$, Merck, Darmstadt, Germany) were used for analytical TLC (Merck, Darmstadt, Germany). High-performance liquid chromatography (HPLC) was performed on a Hitachi L-2130 HPLC apparatus (Hitachi, Tokyo, Japan) with a Supelco C18 column 
$(250 \times 21.2 \mathrm{~mm}, 5 \mu \mathrm{m}$, Supelco, Bellefonte, USA) and a Hitachi L-2455 diode array detector (Hitachi, Tokyo, Japan).

\subsection{Animal Material}

The soft coral Klyxum molle was collected by hand using scuba along the coast of Peng-Hu Islands, Taiwan, in June 2008 at a depth of $10 \mathrm{~m}$, and was stored in a freezer until extraction. A voucher sample (PI-20080610) was deposited at the Department of Marine Biotechnology and Resources, National Sun Yat-sen University.

\subsection{Extraction and Separation}

The frozen bodies of $K$. molle $(1.3 \mathrm{~kg}$, wet weight) were sliced and exhaustively extracted with EtOAc $(3 \times 10 \mathrm{~L})$. The organic extract was concentrated to an aqueous suspension and was partitioned between EtOAc and $\mathrm{H}_{2} \mathrm{O}$. The EtOAc layer was dried with anhydrous $\mathrm{Na}_{2} \mathrm{SO}_{4}$. After removal of solvent in vacuo, the residue (22 g) was subjected to column chromatography on silica gel and eluted with EtOAc in $n$-hexane $(0 \%-100 \%$ of EtOAc, gradient) and further with $\mathrm{MeOH}$ in EtOAc of increasing polarity to yield 31 fractions. Fraction 18, eluted with $n$-hexane-EtOAc (8:1), was further chromatographed over silica gel with a gradient elution using a minture of $n$-hexane-acetone $(7: 1)$ to afford three subfractions (F18B1-F18B3) and compound 7 (39.6 mg). Subfractions F18B1 was subjected to reversed-phase HPLC $\left(\mathrm{CH}_{3} \mathrm{CN}-\mathrm{H}_{2} \mathrm{O}, 1.2: 1\right.$ to $\left.1.6: 1\right)$ in order to purify compounds 3 $(4.0 \mathrm{mg}), \mathbf{4}(7.4 \mathrm{mg}), \mathbf{5}(4.7 \mathrm{mg})$ and $\mathbf{6}(9.2 \mathrm{mg})$. Fraction 20, obtained from $n$-hexane-EtOAc (1:2), was further purified over silica gel using $n$-hexane-acetone (4:1) to afford four subfractions (F20B1-F20B4). Subfraction F20B4 was separated by reversed-phase HPLC $\left(\mathrm{CH}_{3} \mathrm{CN}-\mathrm{H}_{2} \mathrm{O}, 1: 1\right)$ to afford compounds $\mathbf{1}(1.5 \mathrm{mg})$ and $\mathbf{2}(1.7 \mathrm{mg})$.

Klymollin T (1): colorless oil; $[\alpha]_{\mathrm{D}}^{25}-67$ (c 0.15, $\mathrm{CHCl}_{3}$ ); IR (neat) $v_{\max } 3481,2956,2922,2874$, 2852, 1746, 1456, 1372, 1240, 1098 and $1043 \mathrm{~cm}^{-1} ;{ }^{13} \mathrm{C}$ and ${ }^{1} \mathrm{H}$ NMR data $\left(500 \mathrm{MHz} ; \mathrm{C}_{6} \mathrm{D}_{6}\right)$, see Table 1; ESIMS $m / z 545[\mathrm{M}+\mathrm{Na}]^{+}$; HRESIMS $\mathrm{m} / z 545.2722\left[\mathrm{M}+\mathrm{Na}^{+}\right.$(calcd for $\left.\mathrm{C}_{27} \mathrm{H}_{40} \mathrm{O}_{11} \mathrm{Na}, 525.2726\right)$.

Klymollin U (2): colorless oil; $[\alpha]_{\mathrm{D}}^{25}-57$ (c 0.17, $\mathrm{CHCl}_{3}$ ); IR (neat) $v_{\max } 3481,2958,2927,2875$, 2854, 1735, 1456, 1370, 1243, 1098 and $1043 \mathrm{~cm}^{-1} ;{ }^{13} \mathrm{C}$ and ${ }^{1} \mathrm{H}$ NMR data $\left(400 \mathrm{MHz} ; \mathrm{CDCl}_{3}\right.$ ), see Table 1; ESIMS $m / z 545[\mathrm{M}+\mathrm{Na}]^{+}$; HRESIMS $m / z 545.2723\left[\mathrm{M}+\mathrm{Na}^{+}\right.$(calcd for $\left.\mathrm{C}_{27} \mathrm{H}_{40} \mathrm{O}_{11} \mathrm{Na}, 545.2726\right)$.

Klymollin V (3): colorless oil; $[\alpha]_{\mathrm{D}}^{25}-18$ (c 1.14, $\mathrm{CHCl}_{3}$ ); IR (neat) $v_{\max } 2953,2931,2877,1735$, 1636, 1467, 1373, 1227, 1183, 1082 and $1038 \mathrm{~cm}^{-1} ;{ }^{13} \mathrm{C}$ and ${ }^{1} \mathrm{H}$ NMR data (400 MHz; $\mathrm{CDCl}_{3}$ ), see Table 1; LRESIMS $m / z 357[\mathrm{M}+\mathrm{Na}]^{+}$; HRESIMS $m / z 357.2405[\mathrm{M}+\mathrm{Na}]^{+}$(calcd for $^{2}$ $\left.\mathrm{C}_{21} \mathrm{H}_{34} \mathrm{O}_{3} \mathrm{Na}, 357.2406\right)$.

Klymollin W (4): colorless oil; $[\alpha]_{\mathrm{D}}^{25}+14$ (c 2.11, $\mathrm{CHCl}_{3}$ ); IR (neat) $v_{\max } 3466,2959,2935,2872$, 1732, 1644, 1448, 1370, 1250, 1103, 1049 and $1023 \mathrm{~cm}^{-1} ;{ }^{13} \mathrm{C}$ and ${ }^{1} \mathrm{H}$ NMR data $\left(400 \mathrm{MHz} ; \mathrm{CDCl}_{3}\right)$, see Table 2; LRESIMS $m / z 445[\mathrm{M}+\mathrm{Na}]^{+}$; HRESIMS $m / z 445.2563[\mathrm{M}+\mathrm{Na}]^{+}$(calcd for $\left.\mathrm{C}_{24} \mathrm{H}_{38} \mathrm{O}_{6} \mathrm{Na}, 445.2566\right)$. 
Klymollin X (5): colorless oil; $[\alpha]_{\mathrm{D}}^{25}+18$ (c 1.34, $\mathrm{CHCl}_{3}$ ); IR (neat) $v_{\max } 3478,2959,2932,2871$, 1735, 1645, 1431, 1371, 1115 and $1021 \mathrm{~cm}^{-1} ;{ }^{13} \mathrm{C}$ and ${ }^{1} \mathrm{H}$ NMR data (400 MHz; $\mathrm{CDCl}_{3}$ ), see Table 2; LRESIMS $m / z 445[\mathrm{M}+\mathrm{Na}]^{+}$; HRESIMS $m / z 445.2568[\mathrm{M}+\mathrm{Na}]^{+}$(calcd for $\mathrm{C}_{24} \mathrm{H}_{38} \mathrm{O}_{6} \mathrm{Na}, 445.2566$ ).

\subsection{Cytotoxicity Testing}

Cell lines were purchased from the American Type Culture Collection (ATCC). Cytotoxicity assays of 3-7 were performed using the MTT [3-(4,5-dimethylthiazol-2-yl)-2,5 diphenyltetrazolium bromide] colorimetric method $[23,24]$.

\subsection{In Vitro Anti-Inflammatory Assay}

Mouse macrophage cell line, RAW264.7, was purchased from ATCC. In vitro anti-inflammatory activities of compounds 1-7 were measured by examining the inhibition of LPS induced upregulation of IL- 6 and TNF- $\alpha$ in macrophages cells [25].

\section{Conclusions}

New eunicellin-based diterpenoids were isolated together with known compounds from the soft coral Klyxum molle. Compound 5 could significantly inhibit the release of IL-6 in LPS-induced mouse RAW264.7 macrophage cell line. Also, compounds $\mathbf{4}$ and $\mathbf{7}$ showed moderate to weak cytotoxicity.

\section{Acknowledgements}

This research was supported by grants from the National Science Council of Taiwan (NSC 102-2113-M-110-001-MY2), Aim for the Top University Program (02C030205) from Ministry of Education of Taiwan and National Sun Yat-sen University-Kaohsiung Medical University Joint Project (NSYSU-KMU 02C030117), awarded to Jyh-Horng Sheu.

\section{Author Contributions}

Ning-Sun Yang and Jyh-Horng Sheu designed the experiment and contributed to manuscript preparation. Fang-Yu Chang, Fang-Jung Hsu and Chi-Jen Tai carried out the experiment and wrote the manuscript. Wen-Chi Wei performed and analyzed the bioassay.

\section{Conflicts of Interest}

The authors declare no conflict of interest.

\section{References}

1. Blunt, J.W.; Copp, B.R.; Keyzers, R.A.; Munro, M.H.; Prinsep, M.R. Marine natural products. Nat. Prod. Rep. 2013, 30, 237-323.

2. Wu, S.-L.; Su, J.-H.; Wen, Z.-H.; Hsu, C.-H.; Chen, B.-W.; Dai, C.-F.; Kuo, Y.-H.; Sheu, J.-H. Simplexins A-I, eunicellin-based diterpenoids from the soft coral Klyxum simplex. J. Nat. Prod. 2009, 72, 994-1000. 
3. Chen, B.-W.; Wu, Y.-C.; Chiang, M.Y.; Su, J.-H.; Wang, W.-H.; Fan, T.-Y.; Sheu, J.-H. Eunicellin-based diterpenoids from the cultured soft coral Klyxum simplex. Tetrahedron 2009, 65, 7016-7022.

4. Chen, Y.-H.; Tai, C.-Y.; Hwang, T.-L.; Weng, C.-F.; Li, J.-J.; Fang, L.-S.; Wang, W.-H.; Wu, Y.-C.; Sung, P.-J. Cladielloides A and B: New eunicellin-type diterpenoids from an Indonesian octocoral Cladiella sp. Mar. Drugs 2010, 8, 2936-2945.

5. Chen, B.-W.; Chang, S.-M.; Huang, C.-Y.; Chao, C.-H.; Su, J.-H.; Wen, Z.-H.; Hsu, C.-H.; Dai, C.-F.; Wu, Y.-C.; Sheu, J.-H. Hirsutalins A-H, eunicellin-based diterpenoids from the soft coral Cladiella hirsuta. J. Nat. Prod. 2010, 73, 1785-1791.

6. Hassan, H.M.; Khanfar, M.A.; Elnagar, A.Y.; Mohammed, R.; Shaala, L.A.; Youssef, D.T.A.; Hifnawy, M.S.; El Sayed, K.A. Pachycladins A-E, prostate cancer invasion and migration inhibitory eunicellin-based diterpenoids from the Red Sea soft coral Cladiella pachyclados. J. Nat. Prod. 2010, 73, 848-853.

7. Chen, B.-W.; Chao, C.-H.; Su, J.-H.; Wen, Z.-H.; Sung, P.-J.; Sheu, J.-H. Anti-inflammatory eunicellin-based diterpenoids from the cultured soft coral Klyxum simplex. Org. Biomol. Chem. 2010, 8, 2363-2366.

8. Wu, S.-L.; Su, J.-H.; Lu, Y.; Chen, B.-W.; Huang, C.-Y.; Wen, Z.-H.; Kuo, Y.-H.; Sheu, J.-H. Simplexins J-O, eunicellin-based diterpenoids from a Dongsha Atoll soft coral Klyxum simplex. Bull. Chem. Soc. Jpn. 2011, 84, 626-632.

9. Chen, Y.-H.; Tai, C.-Y.; Su, Y.-D.; Chang, Y.-C.; Lu, M.-C.; Weng, C.-F.; Su, J.-H.; Hwang, T.-L.; Wu, Y.-C.; Sung, P.-J. Discovery of new eunicellins from an Indonesian octocoral Cladiella sp. Mar. Drugs 2011, 9, 934-943.

10. Tai, C.-J.; Su, J.-H.; Huang, M.-S.; Wen, Z.-H.; Dai, C.-F.; Sheu, J.-H. Bioactive eunicellin-based diterpenoids from the soft coral Cladiella krempfi. Mar. Drugs 2011, 9, 2036-2045.

11. Lee, Y.-N.; Tai, C.-J.; Hwang, T.-L.; Sheu, J.-H. Krempfielins J-M, new eunicellin-based diterpenoids from the soft coral Cladiella krempfi. Mar. Drugs 2013, 11, 2741-2750.

12. Tai, C.-J.; Su, J.-H.; Huang, C.-Y.; Huang, M.-S.; Wen, Z.-H.; Dai, C.-F.; Sheu, J.-H. Cytotoxic and anti-inflammatory eunicellin-based diterpenoids from the soft coral Cladiella krempfi. Mar. Drugs 2013, 11, 788-799.

13. Cai, Y.-S.; Yao, L.-G.; Di Pascale, A.; Irace, C.; Mollo, E.; Taglialatela-Scafati, O.; Guo, Y.-W. Polyoxygenated diterpenoids of the eunicellin-type from the Chinese soft coral Cladiella krempfi. Tetrahedron 2013, 69, 2214-2219.

14. Chen, T.-H.; Lu, M.-C.; Chang, Y.-C.; Su, Y.-D.; Chen, Y.-H.; Lin, N.-C.; Fang, L.-S.; Wu, Y.-C.; Sung, P.-J. Discovery of new eunicellin-based diterpenoids from a Formosan soft coral Cladiella sp. Mar. Drugs 2013, 11, 4585-4593.

15. Shih, F.-Y.; Chen, T.-H.; Lu, M.-C.; Chen, W.-F.; Wen, Z.-H.; Kuo, Y.-H.; Sung, P.-J. Cladieunicellins $\mathrm{K}$ and $\mathrm{L}$, new eunicellin-based diterpenoids from an octocoral Cladiella sp. Int. J. Mol. Sci. 2013, 14, 21781-21789.

16. Chen, B.-W.; Wang, S.-Y.; Huang, C.-Y.; Chen, S.-L.; Wu, Y.-C.; Sheu, J.-H. Hirsutalins I-M, eunicellin-based diterpenoids from the soft coral Cladiella hirsuta. Tetrahedron 2013, 69, 2296-2301. 
17. Li, T.-T.; Tang, X.-L.; Chen, C.-L.; Zhang, X.-W.; Wu, R.-C.; Zhu, H.-Y.; Li, P.-L.; Li, G.-Q. New eunicellin diterpenes and 9,10-secosteroids from the gorgonian Muricella sibogae. Helv. Chim. Acta 2013, 96, 21781-21789.

18. Lai, D.; Liu, D.; Deng, Z.; van Ofwegen, L.; Proksch, P.; Lin, W. Antifouling eunicellin-type diterpenoids from the gorgonian Astrogorgia sp. J. Nat. Prod. 2012, 75, 1595-1602.

19. Hsu, F.-J.; Chen, B.-W.; Wen, Z.-H.; Huang, C.-Y.; Dai, C.-F.; Su, J.-H.; Wu, Y.-C.; Sheu, J.-H. Klymollins A-H, bioactive eunicellin-based diterpenoids from the Formosan soft coral Klyxum molle. J. Nat. Prod. 2011, 74, 2467-2471.

20. Lin, M.-C.; Chen, B.-W.; Huang, C.-Y.; Dai, C.-F.; Hwang, T.-L.; Sheu, J.-H. Eunicellin-based diterpenoids from the Formosan soft coral Klyxum molle with inhibitory activity on superoxide generation and elastase release by neutrophils. J. Nat. Prod. 2013, 76, 1661-1667.

21. Sharma, P.; Alam, M. Sclerophytins A and B. Isolation and structures of novel cytotoxic diterpenes from the marine coral Sclerophytum capitalis. J. Chem. Soc. Perkin Trans. I 1988, 2537-2540.

22. Wei, W.-C.; Sung, P.-J.; Duh, C.-Y.; Chen, B.-W.; Sheu, J.-H.; Yang, N.-S. Anti-inflammatory activities of natural products isolated from soft corals of Taiwan between 2008 and 2012. Mar. Drugs 2013, 11, 4083-4126.

23. Alley, M.C.; Scudiero, D.A.; Monks, A.; Hursey, M.L.; Czerwinski, M.J.; Fine, D.L.; Abbott, B.J.; Mayo, J.G.; Shoemaker, R.H.; Boyd, M.R. Feasibility of drug screening with panels of human tumor cell lines using a microculture tetrazolium assay. Cancer Res. 1988, 48, 589-601.

24. Scudiero, D.A.; Shoemaker, R.H.; Paull, K.D.; Monks, A.; Tierney, S.; Nofziger, T.H.; Currens, M.J.; Seniff, D.; Boyd, M.R. Evaluation of a soluble tetrazolium/formazan assay for cell growth and drug sensitivity in culture using human and other tumor cell lines. Cancer Res. 1988, $48,4827-4833$.

25. Wei, W.-C.; Lin, S.-Y.; Chen, Y.-J.; Wen, C.-C.; Huang, C.-Y.; Palanisamy, A.; Yang, N.-S.; Sheu, J.-H. Topical application of marine briarane-type diterpenes effectively inhibits 12-O-tetradecanoylphorbol-13-acetate-induced inflammation and dermatitis in murine skin. J. Biomed. Sci. 2011, 18, 94.

(C) 2014 by the authors; licensee MDPI, Basel, Switzerland. This article is an open access article distributed under the terms and conditions of the Creative Commons Attribution license (http://creativecommons.org/licenses/by/3.0/). 